\title{
TORCH seroprevalence among patients attending Obstetric Care Clinic of Haydarpasa Training and Research Hospital affiliated to Association of Istanbul Northern Anatolia Public Hospitals
}

\author{
Onur Numan, Fisun Vural, Nurettin Aka, Murat Alpay, Ayse Deniz Erturk Coskun \\ Department of Obstetrics and Gynaecology, Haydarpasa Numune Training and Research Hospital, Istanbul, Turkey
}

\begin{abstract}
OBJECTIVE: Toxoplasma gondii, Rubella, Cytomegalovirus and Herpes simplex viruses are microorganisms that cause congenital infections and they are called briefly as TORCH. There is an ongoing argument for the screening of reproductive age women due to the high cost of tests. For a test to be used in screening, prevalence of disease in this population should be known. The aim of this study was to investigate TORCH seroprevalence among women attending a teaching hospital in Istanbul.
\end{abstract}

METHODS: A total of 1101 patients attending outpatient clinic of Obstetric Care Clinic of Haydarpasa Training and Research Hospital affiliated to Association of Istanbul Northern Anatolia Public Hospitals between September 2013 to January 2015 and their laboratory data were evaluated retrospectively. We investigated Ig G and M seropositivity rates against TORCH.

RESULTS: The age of the patients ranged between $17-47$ years with a mean age of $30.3 \pm 5.8$ years. Pregnant population had $99.5 \%$ anti-CMV Ig G (+), $94.2 \%$ anti-Rubella Ig G (+), 31\% anti-Toxoplasma Ig G (+). Seroprevalence for Anti IgM was $0.5 \%$ for $\mathrm{CMV}, 0.2 \%$ for rubella.

CONCLUSION: The screening for Toxoplasma gondii may be suggested since the prevalence is not high in our population. The screening of CMV is not meaningful, due to high seroprevalence. Although seroprevalence of rubella is also high, it may be suggested for preconception vaccination especially in women above 20 years of age born prior to National Vaccination Programme.

Keywords: CMV; pregnancy; rubella; screening tests; TORCH; toxoplasma.

$\mathrm{P}$ redominantly members of the TORCH complex microorganisms including Toxoplasma gondii, Rubella and Cytomegalovirus (CMV) many infectious agents lead to the development of a maternal infection and may enter into intrauterine circulation at any gestational age. They sometimes

Received: March 23, 2015 Accepted: December 08, 2015 Online: December 25, 2015

Correspondence: Dr. Fisun VURAL. Haydarpasa Numune Egitim ve Arastirma Hastanesi, Kadin Hastalikları ve Dogum Klinigi, Istanbul, Turkey.

Tel: +90 216 - 5423232 e-mail: fisunvural@yahoo.com.tr

(c) Copyright 2015 by Istanbul Northern Anatolian Association of Public Hospitals - Available online at www.kuzeyklinikleri.com 
lead an asymptomatic course, on the other hand they may encounter us with bad prognosis including miscarriages, sterility, congenital malformations and intrauterine fetal loss [1]. When all the cases were evaluated incidence of intrauterine growth retardation secondary to infectious agents was reported as nearly 5 percent. Prenatal infections have been held responsible from generally $2-3 \%$ of all congenital anomalies $[1,2]$.

Toxoplasma gondii is an intracellular protozoa an agent of parasitic infection known as toxoplasmosis. The spectrum of congenital infection extends from asymptomatic findings up to intrauterine fetal loss and may include chorioretinitis, hearing sequelae, hydrocephalus, mental and psychomotor disorders [3]. As gestational weeks progress, risk of vertical transfer increases and the risk of infection leading to more serious malformations decreases [4]. CMV, is a member of the Herpes viridae species, having deoxyribonucleic acid encased in a nuclear envelope and may remain as a latent microorganism inside host cells. It can affect $0.5-1 \%$ of all live births and it is the most frequently seen agent of congenital viral infections which may lead to sensorineural deafness and mental retardation [5]. Rubella virus is a single-strand RNA virus and it is the infectious agent of rubella (German measles). In $20-50 \%$ of the patients who have this infection, it leads an asymptomatic course. In adults and children the disease manifests itself with adenopathy and severe febrile rashes [6]. The risk of fetal infection is at its highest level during the first 11 week and after the 36. week of gestation [2]. If primary infection is contracted within the first three months, probability of onset of "Congenital Rubella Syndrome (CRS)" is increased [6].

The importance of prenatal care is undebatable in fetal life and neonatal development. Detection of TORCH group of infections which cause a very wide spectrum of damages and gestational complications carries importance. However, necessity of screening of these infectious agents during pregnancy is a debatable issue. The decision to include TORCH group of microorganisms in antenatal screening programs in a certain geographic region may be based on seroprevalence studies conducted at this region. Possible use of a test as a screening test can be decided after regional prevalence studies and evaluations of cost analysis performed by health policy makers, public health specialists and perinatologists [7]. For example, in the United Kingdom surveys are not performed in many regions [8]. In France, screening for Toxoplasma gondii is a must $[9,10]$. However, in our country a complete consensus does not exist on this issue $[1,7,11]$. In this study, the seroprevalence of TORCH group of infectious agents among patients who attended to the Obstetric Care Clinic of Haydarpasa Training and Research Hospital affiliated to Association of Istanbul Northern Anatolia Public Hospitals was evaluated and its use as a screening test was evaluated in the light of the literature.

\section{MATERIALS AND METHODS}

This study was performed on 1101 ambulatory patients who consulted to the Obstetric Care Clinic of Haydarpasa Training and Research Hospital affiliated to Association of Istanbul Northern Anatolia Public Hospitals between September 2013 and January 2015. Hospital files of the patients were retrospectively reviewed, from computer database serologic data of TORCH group of infections were retrieved. Toxoplasma gondii, CMV, Rubella Ig G and Ig M antibodies were analyzed using ELISA method.

\section{RESULTS}

Ages of the patients included in the study ranged between 17 and 47 years and mean age of the pregnants was $30.3 \pm 5.8$ years.

\section{Seroprevalence of TORCH}

In the study, population Ig G positivities for CMV Ig G (99.5\%), rubella (94.2\%) and Toxo (31\%) were detected in respective percentages of patients. The corresponding Ig $\mathrm{M}$ positivities for $\mathrm{CMV}$ and $\mathrm{ru}$ bella were 0.5 , and $0.2 \%$, respectively. Toxoplasma Ig $\mathrm{M}$ positivity was not detected in any patient. A total of $749(69 \%)$ patients were seronegative for toxoplasma. A total of 64 patients were rubella Ig 


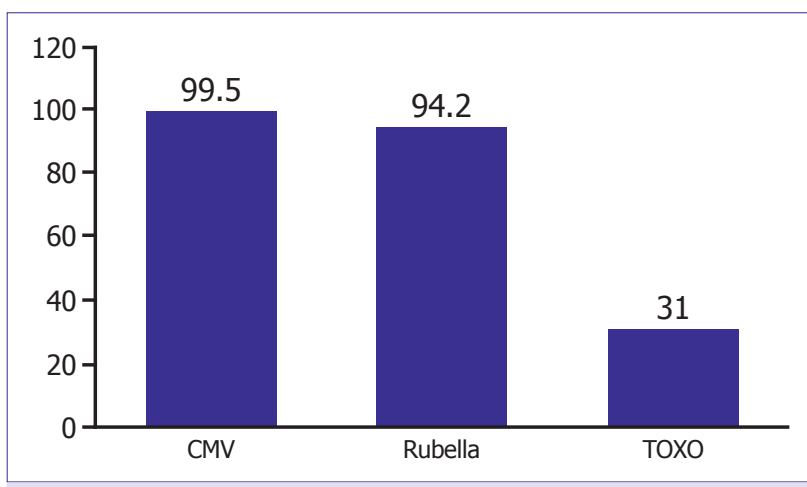

FIGURE 1. TORCH prevalence rates of the pregnants. (The percentage of seropositivity of pregnant women)

G seronegative, while 2 of them were also IgM positive. Serologic analysis of these two patients were performed during the last trimester without causing any problems to the pregnant women and their babies. Serologic tests of 4 patients with CMV Ig $M$ positivity were performed during the second trimester without causing any problem among babies born. Accordingly in $5.8 \%$ of our study population rubella seronegativity was detected. Details are given in Figure 1, and Table 1. Figure 1 presents TORCH IgG seropositivity among pregnant women.

\section{Distribution of rubella seronegativities}

In our country within the context of national vacination program, rubella vaccines are administered. Therefore, seropositivities were evaluated based on age groups of the patients. The patients were divided into 17-25, 26-35 and 36-44 age brackets, and re-evaluated as for Rubella Ig $\mathrm{G}$ according to these

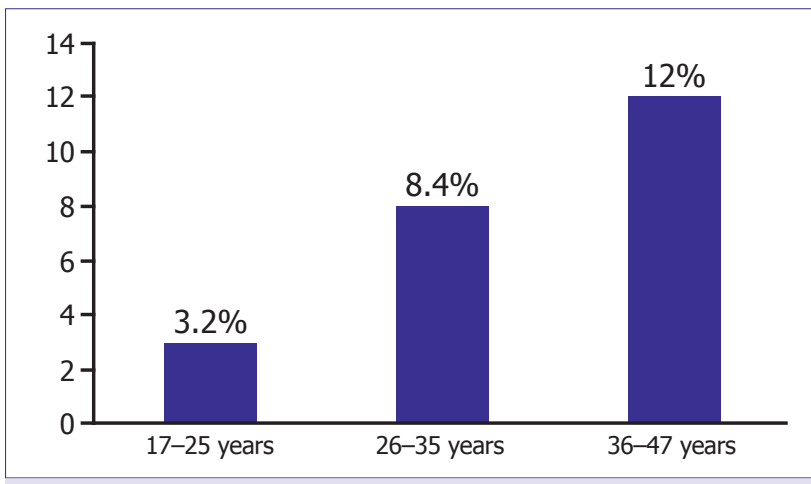

FIGURE 2. Rubella IgG seronegativity in various age groups.

age groups. Accordingly, rubella Ig G seronegativities differed among age groups of 17-25 (3.2\%), 26-35 (8.4\%) and 36-47 (12\%) as indicated. Figure 2 presents the seronegativity of Rubella IgG in various age groups. Prevalence of seronegativity increased with age without any statistically significant difference between age groups $(p>0.05)$. National vaccination program was started in the year 1995. Seronegativity was not detected in cases younger than 20 years of age.

\section{DISCUSSION}

Serologic screening tests directed at agents of maternal Rubella, CMV and Toxoplasma gondii infections carry importance so as to prevent related malformations and other worse neonatal outcomes. Prevalence rates obtained as a result of screening tests aimed to detect infectious agents of the dis-

TABLE 1. Seroprevalence rates for TORCH Ig G, and IgM in pregnant women

\begin{tabular}{lcccccc} 
& CMV Ig M & CMV Ig G & Rubella Ig G & Rubella Ig M & TOXO Ig G & TOXO Ig M \\
\hline Positive (n) & 4 & 899 & 1037 & 2 & 336 & 0 \\
Negative (n) & 881 & 5 & 64 & 891 & 749 & 1068 \\
Total & 885 & 904 & 1101 & 893 & 1085 & 1068 \\
Positive (\%) & $\mathbf{0 . 5}$ & $\mathbf{9 9 . 5}$ & $\mathbf{9 4 . 2}$ & $\mathbf{0 . 2}$ & $\mathbf{3 1}$ & $\mathbf{0}$ \\
Negative (\%) & $\mathbf{9 9 . 5}$ & $\mathbf{0 . 5}$ & $\mathbf{5 . 8}$ & $\mathbf{9 9 . 7}$ & $\mathbf{6 9}$ & $\mathbf{1 0 0}$ \\
\hline
\end{tabular}

CMV: Cytomegalovirus; TOXO: Toxoplasma. 
TABLE2. The summary of the some TORCH studies in Turkey

\begin{tabular}{|c|c|c|c|c|c|c|c|}
\hline \multirow[t]{2}{*}{ City } & \multirow[t]{2}{*}{ Authors } & \multicolumn{2}{|c|}{ Toksoplazma (\%) } & \multicolumn{2}{|c|}{ Rubella (\%) } & \multicolumn{2}{|c|}{ CMV (\%) } \\
\hline & & $\operatorname{IgM}+$ & $\mathrm{IgG}+$ & $\operatorname{IgM}+$ & IgG + & $\operatorname{IgM}+$ & $\operatorname{IgG}+$ \\
\hline Denizli & Karabulut et al. [11] & 1.4 & 37 & 0 & 95.1 & 1.2 & 98.7 \\
\hline Kocaeli & Tamer et al. [16] & 0.4 & 48.3 & 0.2 & 96.1 & 0.7 & 96.4 \\
\hline Edirne & Varol et al. [18] & 0.9 & 31.9 & 0.7 & 76.6 & 1.3 & 80.3 \\
\hline Artvin & Inci et al. [17] & 1.3 & 30.3 & 0.3 & 95.2 & 1.6 & 98.6 \\
\hline Hatay & Ocak et al. [14] & 0.54 & 52 & 0.54 & 95 & 0.4 & 94.9 \\
\hline Malatya & Dogan et al. [12] & - & 37.5 & - & - & - & - \\
\hline Afyon & Yilmazer et al. [19] & - & 30.7 & - & 95.1 & - & 92.6 \\
\hline Mardin & Tekin et al. [28] & 4.6 & 17.5 & 0.95 & 76.5 & - & - \\
\hline Van & Karakas et al. [27] & - & - & 4.8 & 95.2 & - & - \\
\hline Samsun & Uyar et al. [26] & - & - & 1.7 & 94.3 & 1 & 97.3 \\
\hline Sanliurfa & Tekay et al. [13] & 3 & 69.5 & - & - & - & - \\
\hline Ankara & Oruc et al. [32] & - & - & - & - & 0.3 & 98.5 \\
\hline Istanbul & Polat et al. [24] & 0.7 & 48 & & & & \\
\hline Istanbul & Selek et al. [25] & 0.7 & 24 & - & - & - & - \\
\hline Istanbul & Our study & 0 & 31 & 0.2 & 94.2 & 0.5 & 99.5 \\
\hline
\end{tabular}

CMV: Cytomegalovirus.

eases included in the TORCH group can change from region to region based on geographical, socioeconomic and cultural values $[7,11]$. In this study, TORCH seroprevalence rates of the patients who consulted to Obstetric Care Clinic of Haydarpasa Training and Research Hospital affiliated to Association of Istanbul Northern Anatolia Public Hospitals were investigated.

Considering the applicability of screening tests in every pregnant woman, its potential cost and necessity of performing these tests are evaluated in combination. Every country can plan its antibody screening test to be performed against infection agent(s) based on national prevalence values [7]. For instance, in a study performed in the United Kingdom which lasted for 10 years, because of fetal findings detected with detailed investigations, the health authorities have concluded that all TORCH screening tests in maternal serum should not be performed in every case. Thus in UK, based on expert comments this screening test can be limited for the investigation of only CMV seropositivity [8]. In a similar study in
Japan, it was reported that serologic screening tests for TORCH have not any significance apart from CMV screening in cases with fetal growth retardation [2]. In France and Austria, toxoplasma screening test is a legal necessity. In France, prevalence of congenital toxoplasmosis is 3.3 for every 10,000 live births, while prevalence of symptomatic infection is 0.34 for every 10.000 live births $[9,10]$.

Clinical manifestations of mild disease emerging after Toxoplasma gondii infection are generally characterized by fever, lassitude and lymphadenopathy. However, congenital infections can lead to pregnancy losses and serious diseases in the newborn as mental retardation, blindness and epilepsy [10]. Infection contracted during early stage of pregnancy has a risk of transmittance to the fetus less than $6 \%$, while during the third trimester this risk ranges between 60 , and 81 percent. On the other hand, during embryogenesis vertical transfer of Toxoplasma gondii is rarely seen, an infection contracted during this period exerts more serious effects on fetus. On the contrary, babies born to mothers who contracted an infection during 
the third trimester are usually asymptomatic $[9,10]$.

In parallel with cultural eating habits and socioeconomic status of the countries, the results of the seroprevalence studies for Toxoplasma gondii demonstrate variations in the world. In France where consumption of underdone red meat is prevalent $71 \%$ seropositivity rates were detected. However in UK seropositivity rates are lower ranging between 7.7 , and 9.1 percent $[8,9,10]$. When other studies on TORCH seroprevalence are taken into consideration, seroprevalence rates for Toxoplasma gondii vary between 30 and 69.5 percent $[11,12]$. Table 2 presents the summary of TORCH studies in Turkey. In our study, anti-toxoplasma Ig G seropositivity was detected as $31 \%$ which is consistent with most of the studies performed in Turkey $[10,11,12,13$, $14,15,16,17,18,19,20,21,22,23,24,25,26,27$, 28]. Cultural differences between regions, rich and variable cuisine culture in Turkey also reflect on this type of studies. In studies conducted in Southeastern Anatolia Region and neighbouring provincences Toxoplasma gondii seropositivity were higher and ranged between 48.4 and 69.5 percent $[7,13,14,15$, $16,17]$. In studies conducted in Turkey, higher toxoplasmosis seroprevalence rates were detected in Urfa (69.5\%; Tekay et al.), Sivas (52.2\%; Duran et al.), Hatay (52.1\%; Ocak et al.), Adıyaman (48.4\%; Kogeliler et al.), and Kocaeli (48.3\%, Tamer et al. [7, 13, $14,15,16]$. Lower seropositivity rates were detected in studies performed in other provinces. Toxoplasma Ig $\mathrm{G}$ positivity rates in different provinces were observed as follows: Artvin (30.3\%; Inci et al.), Edirne (30\%; Varol et al.), Afyon (30.7\%; Yilmazer et al.) Denizli (37\%; Karabulut et al.), Erzurum (24\%; Yigit et al.), Diyarbakir (32.9\%; Gul et al.), Elazig (41\%; Asci et al.), and Van (41\%; Efe et al.) [11, 17, 18, 19, 20, 21, 22, 23]. Previous seroprevalence studies performed in Metropolitan City of Istanbul, toxoplasma Ig G seropositivities were detected as $43 \%$ by Polat et al. and $21 \%$ by Selek et al. in a more recent study [24, 25]. Excluding provinces of Southeastern Anatolia, seroprevalence of toxoplasma changes between 30 and 43 percent. However, in pilot studies performed in various times in the same province, different results have been obtained. It is important to detect seronegative women especially in regions with higher seroprevalence rates, training people so as to ensure consumption of vegetables and fruits after vigorous washing, popularization of the habit of hand washing and refraining from intake of raw or rare cooked meat carry importance as for prevention of maternal and fetal infections. Our study results are consistent with those of the studies performed in our country excluding Southeastern Anatolia region where the toxoplasma seropositivity ranges between 30 and 43 percent. Because of lower seropositivity rates, especially during pregnancy screening for toxoplasma can be recommended. However, studies concerning its cost-effectiveness should be conducted.

Rubella courses with mild degree of rashes and fever in childhood, when it is experienced in the first months of pregnancy, it can lead to pregnancy losses and stillbirths and during the neonatal period it may result in "Congenital Rubella Syndrome" (CRS) [1, $2,3]$. For the possible prevention of vertical transmittance from mother to the fetus, seronegative women should be detected during preconceptional period, and their pregnancies should be planned, and postponed after immunization. In Turkey rubella vaccination program was implemented firstly in the year 1995, and in the year 2006 it was introduced into National Vaccination Calender $[1,7]$. National Vaccination Calender determined by Public Health Agency of Turkey, TR Ministry of Health and Social Welfare in the year 2014 Measles-Rubella-Mumps (MMR) vaccine is administered as a single dose within the first 12 month of life, and booster dose is injected in the first grade of the primary school.

When other seroprevalence studies performed in the world are taken into consideration seropositivity rates for rubella virus were reported as $87 \%$ in The United States of America (USA), 98\% in Spain and $96.3 \%$ in Iran $[10,11]$. In our study, seropositivity rates for rubella was detected as $94.2 \%$ which demonstrates similarities with the results of other relevant studies. Higher seropositivity rates were detected in Denizli (95.1\%; Karabulut et al.) [11], Samsun (94.3\%) [26], Hatay (95\%) [15], Van (99.5\%) [27], and Kocaeli (96.1\%) [16]. Besides, similar rubella seropositivity rates were observed in other regions. Rubella Ig G seropositivity rates were $76.5 \%$, and $76.6 \%$ in Mardin [28], and Edirne 
[18], respectively. These data are important in that they give an idea about whether national vaccination programs have achieved their goals and implemented all over the population, their acceptability by every section of the community and tracking the success of vaccination programs. In our study, we detected that none of 62 patients had ever encountered rubella virus and hadn't developed immunity against the disease. Besides, in our study population, after implementation of our national vaccination program in pregnants aged 20 years and younger, rubella seronegativity was not detected. When national data obtained were evaluated globally, higher prevalence of rubella seropositivity was detected. These data have suggested us that even though lower rubella seronegativity rates were noted, it will be appropriate to screen and immunize women over 20 years of age during preconceptional period.

CMV is the most frequently encountered congenital infection agent and apart from Toxoplasma gondii and Rubella it may emerge as a primary infection or demonstrate recurrences [29]. Therefore, maternal serologic tests may not rule out a new strain of CMV or reactivation of latent maternal infection and congenital infection. Risk of vertical transmittance after primary infection ranges between 30, and $40 \%$, and it emerges after a secondary infection at a rate of 1 percent $[29,30,31]$. Therefore, in pregnant women routine screening tests for CMV is debatable and American College of Obstetrician and Gynecologists (ACOG) does not recommend screening tests for CMV infection [31]. CMV infections are frequently seen in communal life conditions and populations with lower socioeconomic level. In populations with higher seropositivity rates routine screening tests for CMV may not be recommended. Indeed, an effective treatment modality for congenital CMV infection has not been definitively established yet and this test is costly, and clinically useless. In developed countries, CMV seroprevalence is lower, while in developing countries it has a higher seroprevalence. Seropositivity rates were 46.8\% in France, 56.8\% in Australia, 56.3\% in Finland, $78 \%$ in Russia, 92.1\% in Saudi Arabia and $100 \%$ in Thailand $[29,30]$. In studies performed in Turkey CMV seropositivity rates were detected as
92.6\% in Afyon [19], 98.5\% in Ankara [32], 97.3\% in Samsun [26], 98.6\% in Artvin [17], 96.4\% in Kocaeli [16], and $98.7 \%$ in Denizli $[1,9,11]$. However, in our study CMV seroprevalence was detected as $99.5 \%$ which is one of the highest seropositivity rates. This CMV seroprevalence rates demonstrate parallelism with the relevant results of developed and developing countries. When these findings and seroprevalence rates of our country are taken into consideration, we think that CMV screening during pregnancy is not a necessary application.

In conclusion, seroprevalence of TORCH demonstrates changes among countries or even between regions in the same geographic location. When data of our study and relevant available studies performed in our country are investigated, increased $\mathrm{CMV}$ and seropositivity is detected. Because of its higher seropositivity, screening for CMV is not cost-effective and so it should not be recommended. If national vaccination program can be applied fully, then rubella screening tests during pregnancies of women born after the year 1995 will be useless. However, for the time being, if possible it will be appropriate to perform rubella screening tests during preconceptional period and in women over 20 years of age in addition to vaccination of women against rubella before becoming pregnant. Although seroprevalence of toxoplasmaosis changes among regions, since its treatment is possible at the time of diagnosis and its higher seroprevalence (30-43\%) outside the risky regions, it may be presumably included in antenatal screening programs. We think that perinatologists, public health specialists and health policy makers should work in collaboration and cost-effectiveness of the screening for TORCH group of diseases (if any) should be reviewed.

Conflict of Interest: No conflict of interest was declared by the authors.

Financial Disclosure: The authors declared that this study has received no financial support.

\section{REFERENCES}

1. Karacan M, Batukan M, Cebi Z, Berberoglugil M, Levent S, Kir $\mathrm{M}$, et al. Screening cytomegalovirus, rubella and toxoplasma infections in pregnant women with unknown pre-pregnancy serological 
status. Arch Gynecol Obstet 2014;290:1115-20.

2. Yamamoto R, Ishii K, Shimada M, Hayashi S, Hidaka N, Nakayama M, et al. Significance of maternal screening for toxoplasmosis, rubella, cytomegalovirus and herpes simplex virus infection in cases of fetal growth restriction. J Obstet Gynaecol Res 2013;39:653-7.

3. Patel KK, Shrivastava G, Bhatambare G, Bajpai T. Antenatal detection of $\operatorname{Ig} M$ and $\operatorname{Ig} \mathrm{G}$ antibodies to Toxoplasma gondii in a hospital from central India. Int J Health Sys and Disaster Man 2014;2:133-5.

4. Feldman DM, Timms D, Borgida AF. Toxoplasmosis, parvovirus, and cytomegalovirus in pregnancy. Clin Lab Med 2010;30:70920.

5. Gibson CS, MacLennan AH, Goldwater PN, Haan EA, Priest K, Dekker GA; South Australian Cerebral Palsy Research Group. Neurotropic viruses and cerebral palsy: population based case-control study. BMJ 2006;332:76-80.

6. Jahromi AS, Kazemi A, Manshoori G, Madani A, Moosavy SH, Seddigh B. Seroprevalence of Rubella virüs in women with spontaneus abortion. Am J Inf Dis 2011;7:16-9.

7. Duran B, Toktamis A, Erden O, Demirel Y, Mamik BA, Cetin M. Doğum öncesi bakımda tartışmalı bir konu: TORCH taraması. C.Ü. Tip Fakültesi Derg 2002;24:185-90.

8. Abdel-Fattah SA, Bhat A, Illanes S, Bartha JL, Carrington D. TORCH test for fetal medicine indications: only CMV is necessary in the United Kingdom. Prenat Diagn 2005;25:1028-31.

9. Chaudhry SA, Gad N, Koren G. Toxoplasmosis and pregnancy. Can Fam Physician 2014;60:334-6.

10. Remington JS, McLeod R, Wilson CB, Desmonts G. Toxoplasmosis. In: Remington JS, Klein JO, Wilson CB, Nizet V, Maldonado YA eds. Infectious Diseases of the Fetus and Newborn Infant. Elsevier-Saunders, 7th ed, Philadelphia, PA, 2011.p. 918-1041.

11. Karabulut A, Polat Y, Türk M, Isik Balci Y. Evaluation of rubella, toxoplasma gondii and cytomegalo virus seroprevalemces among pregnant women in Denizli province. Turk J Med Sci 2011;41:159-64.

12. Dogan K, Kafkaslı A, Karaman U, Atambay M, Karaoğlu L, Colak C. The rates of seropositivity and seroconversion of toxoplasma infection in pregnant women. Mikrobiyol Bul 2012;46:290-4.

13. Tekay F, Ozbek E. The seroprevalence of Toxoplasma gondii in women from Sanliurfa, a province with a high raw meatball consumption. Turkiye Parazitol Derg 2007;31:176-9.

14. Ocak S, Zeteroglu S, Ozer C, Dolapcioglu K, Gungoren A. Seroprevalence of Toxoplasma gondii, rubella and cytomegalovirus among pregnant women in southern Turkey. Scand J Infect Dis 2007;39:231-4.

15. Kolgelier S, Demiraslan H, Kataş B, Guler D. Seroprevalence of Toxoplasma gondii in Pregnant Women. Dicle Tip Derg 2009;36:170-2.

16. Tamer GS, Dundar D, Caliskan E. Seroprevalence of Toxoplasma gondii, rubella and cytomegalovirus among pregnant women in western region of Turkey. Clin Invest Med 2009;32:43-7.

17. Inci A, Yener C, Güven D. The investigation of toxoplasma, rubella and cytomegalovirus seroprevalancies in pregnant women in a state hospital. Pam Med J 2014;7:143-6.
18. Varol FG, Sayin NC, Soysuren S. Seroprevalance of toxoplasma gondii antibodies in antenatal population of Trakya region. J Turk Soc Obstet Gynecol 2011;8:93-9.

19. Yilmazer M, Altindis M, Cevrioglu S, Fenkci V, Aktepe O, Sirthan E. Toxoplasma, Cytomegalovirus, Rubella, Hepatitis B and Hepatitis C Seropositivity Rates in Pregnant Women Who Live in Afyon Region. Kocatepe Tip Derg 2004;2:49-53.

20. Yigit N, Aktaş AE, Uslu H, Aydın F, Babacan M. Atatürk Üniversitesi Tip Fakültesi Mikrobiyoloji Laboratuvarına gelen toxoplasmosis şüpheli hasta serumlarında Toxoplasma gondii antikorlarının arașt1- rilması. Türkiye Parazitol Derg 2000;24:22-4.

21. Gul K, Dağ MN, Suay A, Mete M, Mete Ö. D.Ü. Tıp Fakültesinin değişik bölümlerine başvuran ve Toxoplasma ön tanısı konmuş hastalarda Toxoplasma antikorlarının dağılımı. Türkiye Parazitol Derg 1994;18:394-7.

22. Asci Z, Seyrek A, Kizirgil A, Doymaz MZ, Yilmaz M. Toxoplasma şüpheli hasta serumlarında anti-Toxoplasma gondii IgG ve IgM antikorlarının araştırılması. Türkiye Parazitol Dergisi 1997;21:245-7.

23. Efe S, Kurdoğlu Z, Korkmaz G. Van yöresindeki gebelerde Sitomegalovirüs, Rubella ve Toksoplazma antikorlarının seroprevalansı. Van Tip Derg 2009;16:6-9.

24. Polat E, Aslan M, Isenkul R, Aygun G, Aksin N, Cepni I, et al. Gebe kadınlarda toxoplasma gondii Ig M ve Ig $\mathrm{G}$ antikorlarının ELISA yöntemi ile araştırılması. T Parazitol Derg 2002; 26:3501 .

25. Selek MB, Bektöre B, Baylan O, Özyurt M. Serological Investigation of Toxoplasma gondii on Pregnant Women and Toxoplasmosis Suspected Patients Between 2012-2014 Years on a Tertiary Training Hospital. Turkiye Parazitol Derg 2015;39:200-4.

26. Uyar Y, Balci A, Akcali A, Cabar C. Prevalence of rubella and cytomegalovirus antibodies among pregnant women in northern Turkey. New Microbiol 2008;31:451-5.

27. Karakas A, Türker T, Arslan E, Turhan V. Investigation of Rubella susceptibility rate among women of chlidbearing age in a private medical center, Van province, Turkey. Türk Hijyen ve Deneysel Biyoloji Dergisi 2010;67:179-84.

28. Tekin A, Deveci Ö, Yula E. The seroprevalence of antibodies against Toxoplasma gondii and Rubella virus among childbearing age women in Mardin province. J Clin Exp Invest 2010;1:81-5.

29. Collinet P, Subtil D, Houfflin-Debarge V, Kacet N, Dewilde A, Puech F. Routine CMV screening during pregnancy. Eur J Obstet Gynecol Reprod Biol 2004;114:3-11.

30. Kenneson A, Cannon MJ. Review and meta-analysis of the epidemiology of congenital cytomegalovirus (CMV) infection. Rev Med Virol 2007;17:253-76.

31. Dollard SC, Staras SA, Amin MM, Schmid DS, Cannon MJ. National prevalence estimates for cytomegalovirus IgM and IgG avidity and association between high IgM antibody titer and low IgG avidity. Clin Vaccine Immunol 2011;18:1895-9.

32. Oruc AS, Celen S, Citil A, Saygan S, Unlu S, Danisman N. Screening of cytomegalovirus seroprevalence among pregnant women in Ankara, Turkey: A controversy in prenatal care. Afr J MicrobiolRes 2011;5:5304-7. 